\title{
BRITISH COMMONWEALTH SCIENTIFIC CONFERENCE, 1952
}

$\mathrm{T}$ HE second British Commonwealth Scientific Conference was held in Canberra and Melbourne during February 18-March 5. The purpose of the Conference was to consider how the fullest possible collaboration between Civil Government scientific organizations of the British Commonwealth could be brought about and to make formal recommendations to that end.

The delegates to the Conference were appointed by the Governments of the United Kingdom and the Colonies, Canada, Australia, NewZealand, South Africa, Southern Rhodesia, Pakistan and Ceylon : the Government of the United States, following an invitation from the Standing Committee, which was transmitted through the Australian Government, had appointed an observer, Dr. J. Wallace Joyce, deputy science adviser to the Department of State. The Government of India found itself unable to be represented, but conveyed its regrets and good wishes for the success of the Conference. The leader of the Canadian delegation and chairman of the Standing Committee, Dr. C. J. Mackenzie, was also prevented, at the last moment, from attending, his place being taken by Dr. E. W. R. Steacie, president-elect of the Canadian National Research Council.

In opening the Conference, the Prime Minister of Australia, the Right Hon. R. G. Menzies, who was accompanied by the Minister-in-Charge of the Commonwealth Scientific and Industrial Research Organization, the Right Hon. R. G. Casey, said that he saw in the Conference a recognition of the fact that modern scientific research is essentially a matter of team-work; to-day, in contrast to the aloneness of the great scientific pioneers, as seen in Wordsworth's "Prelude" :

\section{"Where the statue stood}

Of Newton, with his prism and silent face,

The index of a mind forever

Voyaging through strange seas of thought alone";

if real progress is to be made, no man, scientist or other, can live to himself alone. Team-work is necessary, not among scientists only, but between them and other sections of the community. Science, he pointed out, never provides final solutions, and, by its very successes, creates, whether in peace or war, other problems no less urgent. $\mathrm{He}$ cited the benefits of medical science which, "regrettable as it may seem to some of our friends", have resulted in greatly increasing the span of human life and immeasurably augmenting the problem of matching food production with population growth. As a workaday politician, he felt bound to tell the Conference of his concern that too few of the ideas based on scientific research ever reach the man at the plough or the factory floor. This, he said, is one of the matters to which we must, individually and severally, direct increasing attention. The real business of the organization of scientific research is the getting of the results of research into the service of the people who most need it. No scientist to-day can say he is living for science alone and that what happens to the results of his work is of no concern to him ; it is only in so far as science is used for the benefit of the world community that mankind can come into its full inheritance.

The chairman, Dr. Clunies Ross, said that the task of the Conference was to review the results of the 1946 Conference, to see how far the recommendations of that Conference had led to fuller intra-Commonwealth collaboration in science and the extent to which they could build on the foundations then established. They started with certain handicaps as compared with their predecessors, but enjoyed some compensating advantages. On one hand, the carlier Conference had effectively explored the more obvious fields for collaboration; but, on the other, they had now five years of experience to guide them in their consideration of what was or was not possible. The crux of their problem was to determine how far any attempted integration of effort between Commonwealth countries would be helpful, while avoiding the erection of cumbersome machinery which might lead to a waste both of time and effort. They must approach their task without scepticism but in a mood of sober realism. He hoped that they would not interpret their terms of reference so narrowly as to preclude discussion of matters which, while not necessarily lending themselves to collaboration, are vital to the discharge of their collective responsibilities. Such matters include the training and recruitment of scientific men and the essential dependence of Government scientific institutions on the universities; the methods whereby the application of results of research to industry can best be secured; the conditions under which national scientific organizations, whether they are concerned with industry, agriculture or medicine, can enjoy that freedom of choice of fields for investigation and independence of action in the conduct of research which are necessary for the maintenance of scientific work of a high order.

The plenary sessions of the Conference in Canberra were devoted to the review by heads of delegations of the major scientific developments in their respective countries since 1946, and to the consideration of the steps taken to give effect to the recommendations of the first Conference relating to the holding of specialist conferences on subjects suited to Commonwealth collaboration in research, the movement of scientific men, the exchange of information, and the application of results of research by industry.

On Thursday, February 21, the Conference adjourned, to resume in Melbourne on February 25.

During the stay in Canberra, delegates were given the opportunity of visiting scientific institutions in the city and its environs, including the School of Physical Sciences of the National University, the Solar Observatory at Mount Stromlo, the Commonwealth Forestry School, and the laboratories of the Divisions of Entomology and Plant Industry and the Sections of Wildlife and Land Research and Regional Survey of the Commonwealth Scientific and Industrial Research Organization.

In Melbourne, the main work of the Conference was carried out by a series of committees, the reports of which were submitted to the final plenary sessions 
and will form the main body of the Conference Report.

\section{Methods of Commonwealth Collaboration in Science}

To deal with methods of Commonwealth collaboration in science, three committees were appointed, covering collaboration in industry, agriculture and medicine.

Dr. Steacie, in reporting the conclusions of the Industry Committee, said that, while making no recommendation for the holding of specialist conferences at this stage, the Committee believed that all countries should pay special attention to the following subjects: (i) developments in industrial microbiology, (ii) research on the utilization and beneficiation of low-grade ores, and (iii) research on the use of solar energy by physical and biological means. The Committee also recommended that Commonwealth Governments should be prepared to accept, for training, staff of Government research organizations of another Commonwealth country, and that, where a laboratory already exists which is capable of providing facilities of a special nature, it should be encouraged, in appropriate cases, to undertake work within its field for other Commonwealth countries; in general, it is desirable, in such cases, for staff to be seconded to the laboratory by the countries concerned, on the understanding that the administration of all such laboratories undertaking work for two or more countries should always be the sole responsibility of the parent country.

From its consideration of possible topics suitable for Commonwealth collaboration, the Agricultural Committee, under the chairmanship of Sir William Slater, selected two as being of special importance, namely, infertility of ruminants and agricultural engineering. In relation to the first of these, it was recommended that no action be taken to call a specialist conference, pending the completion of a report from the Food and Agriculture Organization on infectious forms of infertility; when this becomes available, the Standing Committee was asked to consider the desirability of supplementing it by the collection of further data on non-infectious forms of infertility, and eventually calling a conference of specialists to consider physiological and nutritional aspects of the problem, at which United States' workers should also be represented. As to agricultural engineering, the Committee recommended that the Agricultural Research Council of the United Kingdom request the National Institute of Agricultural Engineering to prepare a statement of the means whereby agricultural engineering problems may be defined. When this statement has been critically examined by Commonwealth countries, a decision could be taken on the desirability of calling a specialist conference.

Dr. F. H. K. Green presented the report of the Medical Committee. The Committee recorded its appreciation of the work, as reference laboratories, of the World Influenza Centre and the Public Health Laboratory Service of the United Kingdom. It expressed the hope that other laboratories in Commonwealth countries might be given similar international status for the identification of infective agents and for advice on epidemiological problems in which they have special experience and recognized competence.
Special emphasis was placed on two subjects as suggesting possibilities for international collaboration: (i) environmental physiology of both man and animals, and (ii) geographical anthropometry, which concerns the differences in physical standards between the inhabitants of different countries and between tribal or other groups in the same country. The Standing Committee was asked to arrange a small exploratory meeting of specialists to define the project on which studies might be initiated.

The Medical Committee, in common with the Agricultural Committee, recommended that the attention of Governments be directed to the grave impact of medical research on the world's food and population problem. The benefits of agricultural research and development for the increase of food production has been more than offset, in many countries, by the success of medical science in decreasing mortality from infectious and other diseases. There is urgent need for joint discussion by the World Health and the Food and Agriculture Organizations of the inter-relationships of their programmes.

\section{Information Services}

Dr. P. J. du Toit, chairman of the Information Committee, directed attention to the value of publication by the United Kingdom of research in progress in the universities, the Department of Scientific and Industrial Research, and the Agricultural Research Council, and recommended that each Commonwealth country should be invited to take similar action. The Committee pointed out the grave financial and other difficulties facing some of the most valuable scientific abstracting services, as a consequence of which these services may be either curtailed or suspended. It considered that every effort should be made to avoid duplication of effort by English-language abstracting services and invited the Standing Committee of the Conference to consider all measures necessary to maintain such services, including, if necessary, recommendations to governments for joint financial assistance to them.

\section{Application of the Results of Research}

Two Committees were appointed to consider the application of the results of research, in industry and agriculture respectively.

The Industrial Committee, under the chairmanship of Sir Ben Lockspeiser, while recognizing the importance of economic, political and other factors, concluded that technological improvement or innovation is the most important single factor leading to increases in productivity. It is the duty, therefore, of scientific organizations of all Commonwealth countries to consider this problem as one of the highest importance, to relate their research programmes to economic needs, and, in view of the high cost of technological development, to be prepared, where necessary, to carry research to the pilot-plant stage of development. Attention was directed to the fact that, since the last British Commonwealth Scientific Conference, the United Kingdom, Canada and India had established corporations for promoting the development of results of research, particularly those arising in individual laboratories, universities and research associations. A further expansion of the same principle has been the setting up by several research associations of companies on commercial 
lines, to arrange for the development and exploitation of successful researches.

After reviewing the several information techniques, the Committee emphasized the importance of the human factor in all aspects of the efficient application of science to industry. Although research institutions should not necessarily accept responsibility for research involving human factors, the subject is. of such importance as to deserve their earnest attention. The South African Council for Scientific and Industrial Research has intervened directly in this field through its Institute of Personnel Research.

Whatever the measures undertaken by government agencies, however, there is no substitute for a due proportion of scientific workers and technologists within industry itself, at all stages of management and production, from the board table to the workshop floor.

The Agriculture Committee, under the chairmanship of Dr. K. W. Neatby, emphasized the paramount need for a revaluation of the responsibilities, status and qualifications of extension officers. Agricultural extension services must not only attract to themselves men of high intellectual ability and initiative, but also such men must be given every opportunity of keeping abreast of scientific progress by the frequent provision of refresher courses and by giving them access to suitable scientific literature. In this latter connexion, it was felt that a far wider distribution should be made of the excellent abstracting literature of the Commonwealth Agricultural Bureaux. Emphasis was put on the desirability of decentralizing extension services to the maximum possible and of enlisting the co-operation of the more progressive farmers in a district in the dissemination of knowledge.

\section{Movement of Scientific Men}

The Committee, under the chairmanship of $\mathrm{Mr}$. F. R. Callaghan, noted with satisfaction the improved facilities for scientific men to travel which have been provided by governments and bodies such as the Nuffield Foundation, the British Council, the National Research Council of Canada, and the Fulbright Foundation. On the other hand, attention was directed to the difficulties facing the holders of scholarships and travelling grants, due to the continuing rise of living and travel costs. All countries were urged to keep this matter under review and to take necessary steps to increase the value of such grants to meet the changing economic conditions.

It was particularly gratifying that certain airline companies had recently made considerable donations towards the cost of travel by students.

Other Committees, under the chairmanship, respectively, of Dr. F. W. G. White and Dr. Alexander King, submitted reports on the Commonwealth Scientific Liaison Offices and International Scientific Relations.

\section{National Organization of Research}

The Conference approved a statement which sought to provide a common basis for agreement on the functions, administration and relations with the universities on one hand and industry on the other of national scientific organizations. The statement stressed the dependence of scientific effort in any country upon the universities and the facilities they possess for training, and particularly postgraduate training, and research. No hard-and-fast rule can be laid down for carrying out the national scientific organizations' research programmes: the governing body should decide whether it is preferable to establish laboratories under its own auspices or encourage the establishment of laboratories by independent agencies; make grants to universities or other research institutions; or to combine these methods. The governing body, composed of senior men of science, should be directly responsible to a Minister but otherwise should be freed from all political control or influence, whether in relation to the selection of the main fields for scientific investigation, the allocation of effort between these, or the appointment and promotion of staff. Once broad lines of policy have been determined by the governing body, the executive officers appointed for their scientific knowledge or administrative ability should have complete responsibility for their general implementation, as should directors of laboratories for the conduct of the actual research programme.

Between the Canberra and Melbourne sessions of the Conference, delegates were taken, as guests of the Australian Government, for a four-day trip by road between the capitals in order to allow them to see something of the pastoral and agricultural activities of south-eastern Australia. The party travelled first through the high tablelands of southern New South Wales, which are largely given over to fine merino wool production, then west through the lower and more fertile wheat-growing and fat-lamb producing areas of the western slopes of the Great Dividing Range.

On the second day, the route was again to the west and, by midday, had reached the Riverina Plains between the Murrumbidgee and Murray Rivers, one of the most important stud-sheep producing areas of the Commonwealth. The trip was enlivened at this stage by what, for most of the delegates, was their first sight of wild kangaroos. At "Boonoke" Station, the largest sheep stud, it is believed, in the world, which runs some 300,000 stud sheep and sells more than 8,000 stud rams each year, the owner, the Hon. O. McL. Falkiner, had rounded up large numbers of kangaroos and emus, and the visitors were entertained by the sight of jeeps and $A .90$ Austin cars mustering these unusual livestock at some 40 miles an hour. Some of the delegates had the good fortune of travelling with the owner in his Austin and were able to gauge the maximum speed of the emu at approximately 30 m.p.h., and of the kangaroo at up to 35 m.p.h., the former being found capable of maintaining a high speed for almost ten miles. The paddock mustered was a heavily grassed, treeless plain more than 5,000 acres in area.

On the third day, the party crossed the Murray River into Victoria and inspected the Soldier Settlements, where former extensive sheep runs are being converted to irrigated dairy farms and orchards varying in size from 40 to 100 acres. The route then lay through the Goulburn Valley, one of the most intensively developed irrigation areas in Australia, which provided examples of fruit and vegetable production, cereal and other fibre crops, and dairying, beef and fat lamb production.

On the final day, the route to Melbourne ran to the south-east, passing through the Cumberland Forest, where magnificent stands of mountain ash (Eucalyptus regnans) occur, some specimens of these, up to $300 \mathrm{ft}$. high, being perhaps the tallest known hardwoods. 
'The last stop was made at the Eildon Weir, on the headwaters of the Goulburn River, where the Utah Construction Co. of the United States, on behalf of the Victorian Government, is enlarging the capacity of the existing weir from 306,000 acre $\mathrm{ft}$. to $2 \frac{3}{4}$ million acre ft.; the enlarged dam will make possible the generation of 120,000 kilowatts of hydro-electric power.

On arrival in Melbourne, with a temperature of $90^{\circ}$ in the shade, delegates, while a little dusty and dishevelled, were agreed that they had gained an appreciation, which would not have been possible in any other way, of some of the problems and possibilities of the Australian environment.

\section{ELECTRIC WHALING BY ROBERT CLARKE National Institute of Oceanography}

$I^{T}$ is appropriate that recent publicity given to the Iectric harpoon should come in the centenary year of this method of killing whales. On March 30, 1852, Dr. Albert Sonnenberg and Phillip Rechter, of Bremen, Germany, patented an 'electric whaling apparatus' which was to be installed in a conventional open whaleboat of the period ${ }^{1,2}$. The hemp whale-line, bearing a wire conductor, was to be fastened to the whale with the customary hand harpoon: thereupon the hand-operated induction machine would generate "so formidable a power that no living being can resist the same"; the current was to return through the water to the boat, specially copper-bottomed for this purpose. This apparatus, although doubtless impracticable and never tried out, clearly embodied the essentials of the modern development.

The hand harpoon of those days was to be eventually ousted by a heavy projectile, bearing an explosive grenade in its barbed head, and fired from a cannon mounted in the bows of a small steam vessel. Developed by the Norwegian, Svend Foyn, between 1864 and $1873^{3}$, this bomb-harpoon, persisting virtually unaltered, has made possible the modern whaling industry. It has, however, various disadvantages. The maximum range is not much more than thirty yards. The bursting grenade spoils some of the meat, and frequently ruptures the gut, thereby releasing the intestinal flora and so accelerating decomposition of the carcass: sometimes the hoggers of a meat-meal plant are damaged by overlooked splinters of a grenade. (It may be said at once that these processing drawbacks are quite overcome by an electrocution technique.) The industry would also profit by a method which killed more whales in a given time, and which reduced the losses from sinking of a proportion of grenade-killed whales before they can be ranged alongside a catcher and inflated with air. Finally, and not least important, there is the suffering inflicted by the bombharpoon: it may kill outright, but usually the killing takes ten or twenty minutes and sometimes much longer.

Most promise of improvement seems to lie in electric whaling. Early experiments with the electric harpoon, in 1881 and 1904, were unsuccessful, but in 1929 a German engineer called Weber became interested and a company, A/S Elektrisk Hvalskytning, was formed in Oslo. The company did not forget to consult American experts on the electric chair. Eventually four fin whales were electrocuted. Weber improved his apparatus and by 1938 the electric harpoon is said to have accounted for about two thousand whales during six expeditions north and south ${ }^{4}$.

Weber committed suicide in 1945 ; but some account of his methods has been published ${ }^{5,6}$. A fundamental need was to safeguard the gunner and the catcher crew. The conventional harpoon gun was therefore fitted with a recoil switch, so that the circuit was not completed until the harpoon had left the gun. A dynamo generated 200 volts at 50 cycles: the current varied according to the position of the hit. The heart and lungs took 78-90 amp. and death was instantaneous. More usual, and considered most effective, was a hit in the dorsal muscle which took 35-60 amp. Death ensued between ten seconds and two minutes afterwards, and could be recognized by the collapsing of the flippers and the opening of the mouth. The abdomen took more current (80-90 amp.). A 'partial hit', with one barb projecting and shorting to the sea, caused a load of $100 \mathrm{amp}$.; but might only paralyse and not kill the whale. A miss naturally short-circuited the current.

With a good hit, this is a merciful method of killing. Furthermore, the electrocuted whales usually float, tetanus overcoming them while their lungs are still full of air. Of two hundred electrocuted whales, the catcher Star 14 lost only two from sinking?. Perhaps most significant in an industry where time is everything during a restricted season, operators claimed that the time spent in securing a hit, killing the whale, heaving-to, inflating and flagging the whale, and finally resuming the chase, was reduced from around forty-five minutes in grenade whaling to ten minutes in electric whaling.

Nevertheless, in pre-war years the electric harpoon was not regarded seriously by Norwegian gunners, perhaps not least because of a tale I heard in the south of an electrocuted blue whale which, being secured alongside the whalecatcher, suddenly became embarrassingly alive.

Since the Second World War there has been renewed interest in electric whaling. The main reviving impetus has come from Britain, and a statement describing some recent progress has been released by the General Electric Co., Ltd. At present the firm of United Whalers, Ltd., is co-operating with the G.E.C. and with manufacturers of guns, ropes and cables, in a vigorous programme to develop the electric harpoon. Norway shares the revival, and the Electrohval Company in Oslo maintains liaison with the British investigators. Japan is also experimenting with electrical methods, in conjunction with a 'flattened-head' harpoon said to diminish ricochet without impairing penetration $^{8}$.

British interest owes a good deal to the energy of Dr. H. R. Lillie, a surgeon who returned from the Antarctic whaling season of 1946-47 alarmed by the suffering caused among whales by the bomb-harpoon? The Universities Federation for Animal Welfare took up his cause, and, led by Major C. W. Hume, they were able to interest United Whalers, Ltd., in the need for a more humane method and one which might also benefit the industry. Electric whaling was the obvious choice. A successful search was made for Weber's papers, and a catcher was equipped for electric whaling in time for the 1948-49 Antarctic 